\title{
Interpretations of aeromagnetic data over lokoja and environs, Nigeria
}

\author{
Chinwuko Augustine Ifeanyi ${ }^{1 *}$, Usman, Ayatu Ojonugwa ${ }^{1}$, Onwuemesi Ajana Godwin ${ }^{1}$, Anakwuba Emmanuel \\ Kenechukwu ${ }^{1}$, Okonkwo Churchill Chukwunonso ${ }^{2}$, Ikumbur Emmanuel Bemsen ${ }^{3}$ \\ ${ }^{1}$ Department of Geological Sciences, Nnamdi Azikiwe University, Awka, Nigeria \\ ${ }^{2}$ Department of Physics, Federal College of Education (Technical), Umunze, Nigeria \\ ${ }^{3}$ Department of Geology, Benue State Polytechnic Ugbokolo, Nigeria \\ *Corresponding author E-mail: ozochinwuko1@yahoo.com
}

\begin{abstract}
Total field aeromagnetic anomalies over Kogi-Auchi area have been evaluated in order to map the magnetic lineaments and estimate the depth to basement (sedimentary thicknesses). Aeromagnetic and radiometric data of the area (sheet 246, 247, 266 and 267) were acquired, digitized and analyzed. The slope methods were applied in the analysis of the residual contour map. The result obtained using the slope methods reveals two depth sources in the study area; on the average the deeper magnetic sources range from 2.3 to $4.9 \mathrm{~km}$, while the shallower magnetic sources range from 1.1 to $1.6 \mathrm{~km}$. These shallower sources are probably due to the presence of igneous intrusives and/or magnetized bodies within the sedimentary cover. Visual study of the residual anomaly map shows the presence of igneous intrusive in the entire North and Southwestern part of the study area. The One Vertical Derivative (1VD) lineament map shows the Fault trending in Northwest-Southwest (NW-SW) and Northeast-Southwest (NE-SW) direction and this conforms to the Niger-Benue basin itself. Hydrocarbon exploration is not recommended since the area has low thickness of sediment on the average. All this deduction were reached after due consideration of qualitative and quantitative interpretations supported by geological information of the area.
\end{abstract}

Keywords: Aeromagnetic Data, Radiometric Data, Lineament, Igneous Intrusives, Depth to Basement.

\section{Introduction}

The study area lies within latitudes $7^{\circ} 10^{l} \mathrm{~N}$ to $8^{\circ} 10^{l} \mathrm{~N}$ and longitudes $6^{0} 10^{1}$ and $7^{0} 10^{1} \mathrm{E}$, covering parts of Kogi and Edo States (Fig. I). It falls within the Nigerian Precambrian basement complex, a suite of crystalline rocks exposed in over nearly half of the country extending west into the Dahomeyan of Benin Republic (Amigun, 2009). The dominant lithologic units of the study area are gneisses of migmatite, biotite and granite which are regionally emplaced; the ferruginous quartzite is the source of the iron ore mineralization in the area. (Olade, 1975). From a tectonic point of view, the area is confined to the Southern limb of a large Itakpe Ajabonoko anticline with enclosing rocks and conformable ore layer sticking sub - latitudinally and slightly bending to the north and dipping southward at angles ranging from $40^{\circ}$ to $80^{\circ}$ (Rasheed et al 2011).Furthermore, slope failure is prominant in the study. This may be accounted for as a result of the exploration and mining activities within the area.

Aeromagnetic survey is one of the most important tools used in modern geological mapping (Chinwuko et al., 2012). The principle is similar to a magnetic survey carried out with a hand-held magnetometer but allows much larger areas of the Earth's surface to be covered quickly for regional reconnaissance. The aircraft typically flies in a grid-like pattern with height and line spacing determining the resolution of the data (and cost of the survey per unit area). This survey along a profile or grid determines the strength of the geomagnetic field at particular points by measuring spatial variations in the Earth's magnetic field. Every kind of ma terial has unique magnetic properties even those that we do not think $g$ as being "magnetic". Thus, different materials below the ground can cause local disturbances in the Earth's magnetic field that are detectable with sensitive magnetometers. Ofoegbu (1988) reported that roughly about $60 \%$ of magnetic surveys are carried out for regional geological mapping and mineral exploration purpose while the remainder being mainly for petroleum exploration. Also, Onuba et al (2008) pointed out that the main purpose of magnetic survey is to detect rocks or minerals possessing unusual magnetic properties that reveal themselves by causing disturbances or anomalies in the intensity of the earth magnetic field.

However, this project work covers interpretation of aeromagnetic data over Lokoja and its environ, North Central of Nigeria. The slope method was adopted in this study and this can be used for both mineral and oil exploration. In mineral prospecting it defines the shape of the structure containing such minerals and in oil prospecting, it defines the extent of sedimentary thickness. It is believed that this project work will contribute to a better understanding of the geology of the area and it will provide a guide to future investors.

\section{Geological setting of the study area}

The area fall under the banded iron Formation of Nigeria, generally they occurs in metamorphosed folded bands, associated with Precambrain basement complex rocks which included low metasediments, high grade schist, gneisses and migmatites. Included in this group are well known Lokoja-Okene occurrences notably at Itakpe, Ajabanoko, Chokochoko, Toto MuroandTaijimi. In the 
northwestern parts of Nigeria, the banded iron Formation occurs sporadically in narrow band and lenses inter-bedded with massive green phyllites, feebly developed slaty rock and amphibolites.

The dominated lithologic units in the area are gneisses of migmatite, biotite and granite. Olade, (1975) pointed that the ferruginous $400^{1} \mathrm{E}$

Fig. 1: Geologic Map of Nigeria Showing the Study Area (Obaje, 2009).

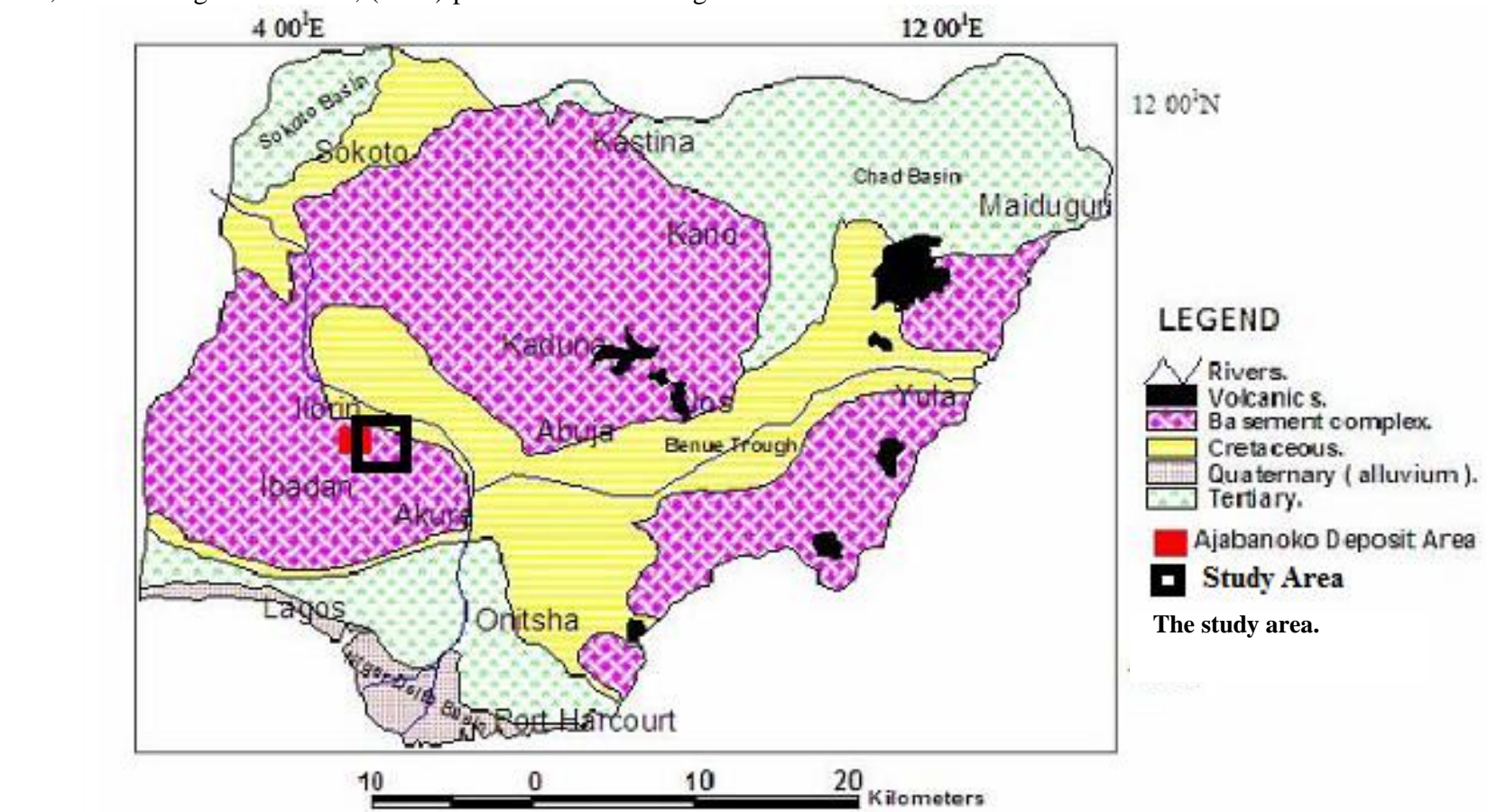

quartzite is the source of the iron ore mineralization. The south eastern part of the study area is more sedimentary.

\section{Methodology}

Four aeromagnetic maps were acquired from National Geological Survey Agency (NGSA), Abuja. These sheets include; sheets 246 (Kabba), 247 (Lokoja), 266 (Auchi) and 267 (Idah). The aeromagnetic data were obtained as part of a nationwide aeromagnetic survey sponsored by geological survey of Nigeria. The data were acquired along a series of NW - SE flight lines with a spacing of $2 \mathrm{~km}$ and an average flight elevation of about $150 \mathrm{~m}$ while tie lines occur at about $20 \mathrm{~km}$ interval. The geomagnetic gradient was removed from the data using the international geomagnetic reference field (IGRF).

Digitization of data is followed by separation of aeromagnetic data. Here, a linear trend surface (equation 1) was fitted on to the digitized aeromagnetic data by a multiple regression technique for the purpose of removing the regional magnetic gradient. The linear surface so fitted was removed from the digitized data so as to obtain the residual anomaly data which was used to construct residual anomaly map. The data were then transformed into regular grid using computer software Surfur- 32 which iteratively carries out interpolation of data and contoured the anomalies (total magnetic field intensity and residual).

The trend surface equation (regional gradient) becomes

$\mathrm{T}(\mathrm{x}, \mathrm{y})=-11177-147.26 \mathrm{x}+217.38 \mathrm{Y}$

Where

$\mathrm{T}(\mathrm{x}, \mathrm{y})$ is the Magnetic value at $\mathrm{x}$ and $\mathrm{y}$ coordinates

$\mathrm{x}$ and $\mathrm{y}$ are units of spacing along the latitude and longitude.

The residual anomaly was subjected to slope method analysis and geologic modeling. Slope method has been widely used by several authors (Spector, 1976, Onuba, 2011, etc.) to determine the depths of magnetic anomalies. The slope method is mostly used as a quick check on the validity of depth estimates. The method gives reasonable results and it is very suitable for anomaly of aeromagnetic data.

\section{Results and discussion}

\subsection{Qualitative Interpretation}

This is done by visual inspection of the map (Fig 2). The closely spaced, linear sub-parallel orientation of contours from northwestern and southwestern part of the study area suggests the possibility of faults or local fractured zones passing through these areas. Chinwuko et al (2012) and Nsikak et al. (2000) generally believe there would always be a magnetic susceptibility contrast across a fracture zone due to oxidation of magnetite to hematite and/or infilling of fracture planes by dyke - like bodies whose magnetic susceptibility are different from those of their host rocks. The main trend of the lineaments from Magnetic maps (Figs.4.1 and 4.2) is NW - SE and NE - SW directions. These structures are concentrated mainly in the sheets 246, 247 and 266. It is also pertinent to point out that NW - SE trending faults are associated with Kibaran Orogeny. This orogeny is marked with geosynclinal sedimentation and metamorphism. Rasheed (2011) has described slightly migmatised (older metasediments) to unmigmatisedmetasediments, metavolcanics, amphibolites and metaconglomerates of southwest Nigeria, associated with charnokites (100 m.y. - Kibaran) in the Ado - Ekiti - Igarra area. In the Igarra - Auchi area, the metaconglomerates, host small quantities of gold in NW - SE trending quartz veins associated with pyrite.

The visual inspection of the aeromagnetic map shows that the contour lines of northwestern and southwestern parts are closely spaced indicating that the depth to basement is shallow in these areas. The southestern parts are widely spaced indicating that the depth to magnetic basement is relatively high when compared to those of northwestern and southwestern parts.

Again, a positive magnetic anomaly is a reading of magnetic field strength that is higher than the regional average which can indicate hidden ore and geologic structures. These positive magnetic contour readings are found in the northwestern and southwestern part of the study area, while a negative magnetic anomaly is a reading 
of magnetic field strength that is lower than the regional average, this is found in the southeastern part of the study area. (Fig 3).

In general, the variation in magnetic intensity across the study area shows a general increase in magnetic intensity from the upper Northwestern part and lower Southwestern part towards the
Southeastern parts. This variation could be a function of the lithology of the basement complex. Also, zone of low magnetic intensity correspond to sedimentary rocks while those of high magnetic intensity are characterized by rocks such as granite and mignitite.
$8^{0} 10^{\prime} \mathrm{N}$

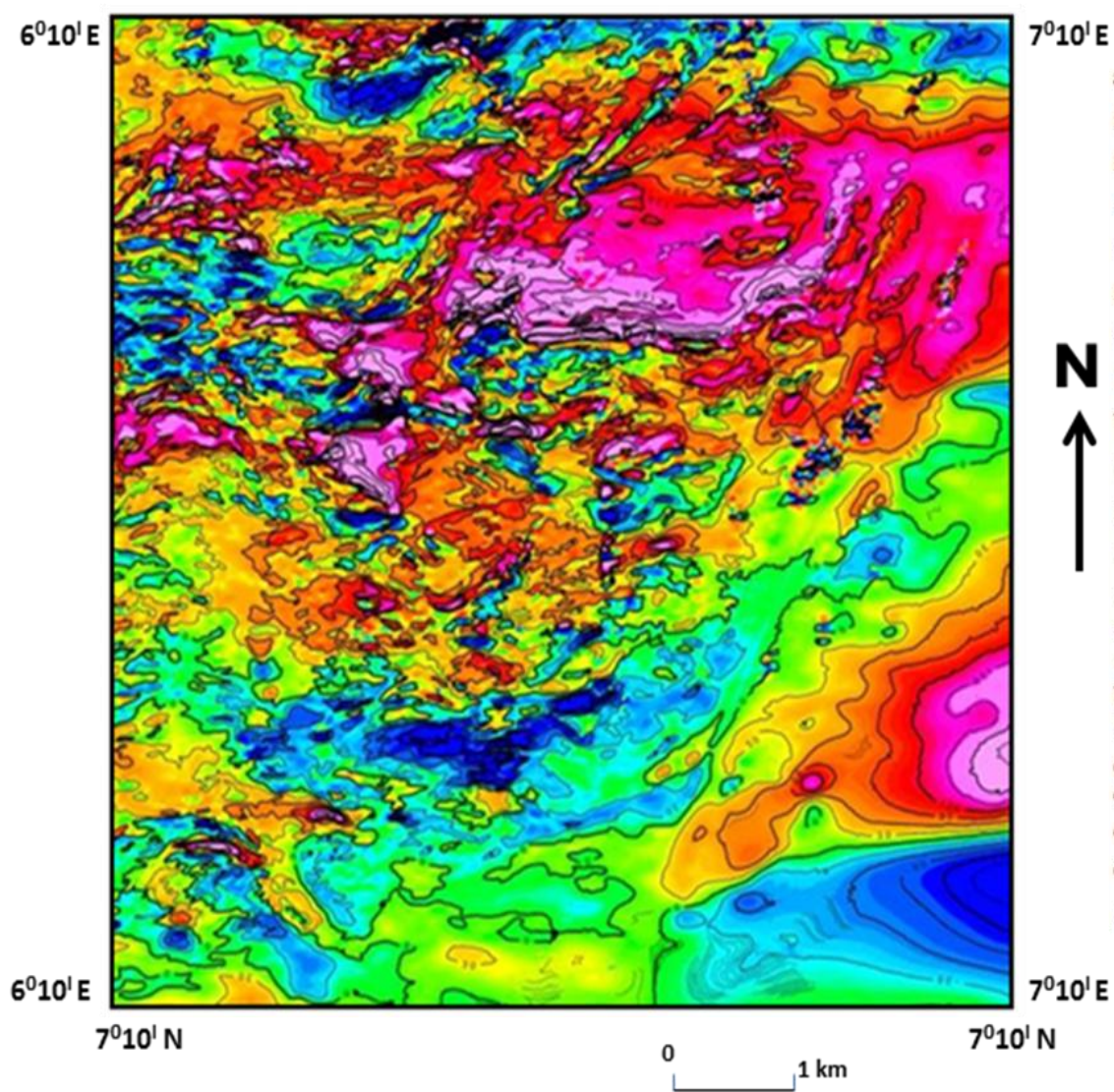

Fig. 2: Total Magnetic Field Intensity of the Study Area. (Contour Interval 30nt)

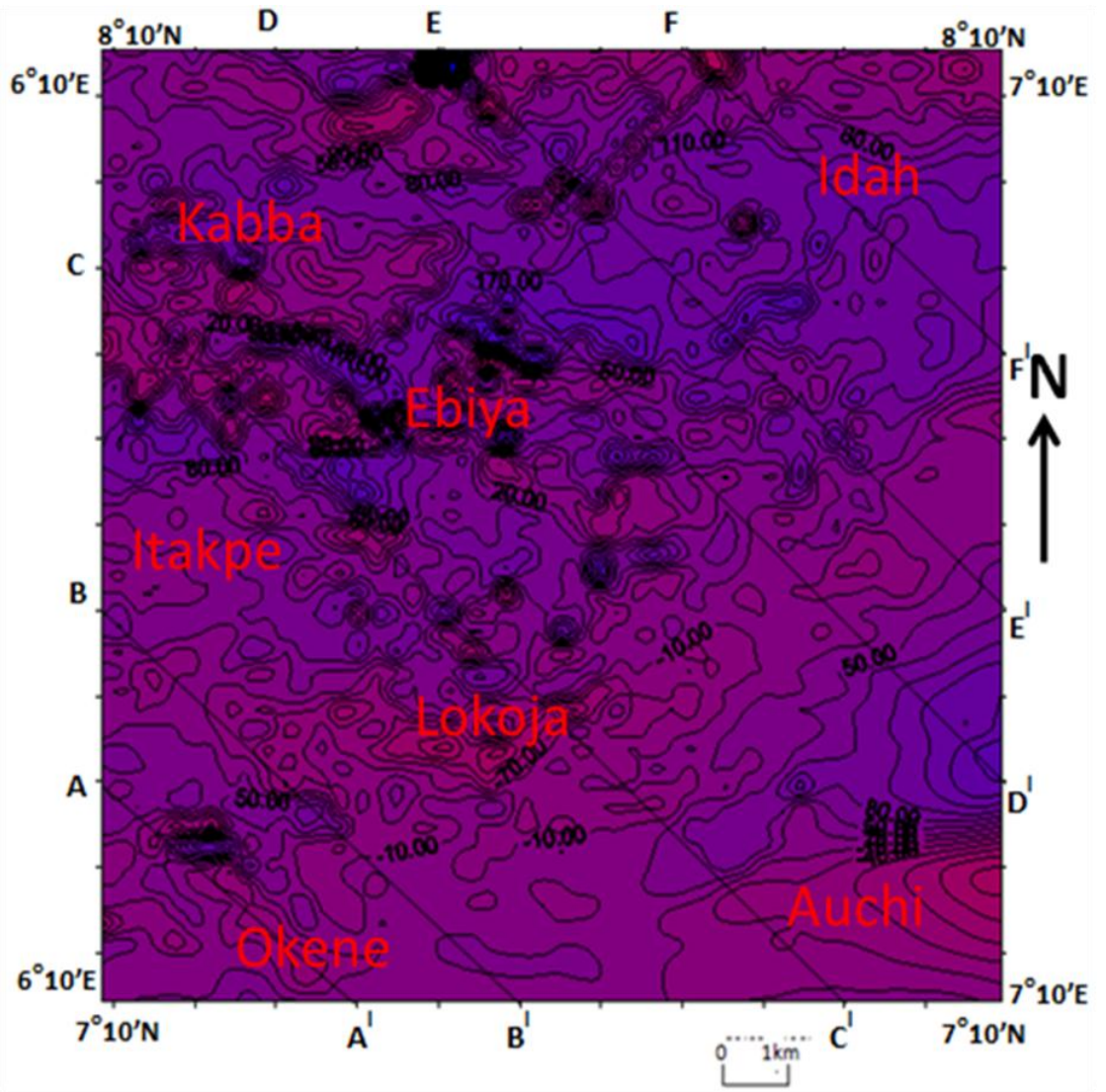

Fig. 3: Residual Anomaly Map of the Study Area with Profile Lines. (Contour Interval 30nt) 


\subsection{Quantitative interpretation}

The most important parameter in quantitative interpretation is the depth of the anomalous body. Depth to source is contained in the shape of the anomaly. Because of the obvious importance of the depth to basement in mineral exploration, the depth to the source usually referred to as the depth to the magnetic basement is of great importance.

In order to estimate depths to basements (thickness of sediments) across the study area, the slope method of interpretation was deployed. Six profiles were taken on the residual aeromagnetic anomaly map of the study area. (Fig.3). This profiles were taken perpendicular to the direction of the magnetic profiles, namely, A$\mathrm{A}^{\mathrm{I}}, \mathrm{B}-\mathrm{B}^{\mathrm{I}}, \mathrm{C}-\mathrm{C}^{\mathrm{I}}, \mathrm{D}-\mathrm{D}^{\mathrm{I}}, \mathrm{E}-\mathrm{E}^{\mathrm{I}}$, and $\mathrm{F}-\mathrm{F}^{\mathrm{I}}$, were used for detailed interpretation (Fig. 4) and these may serve as representatives of other as they behave almost in the same way. The result of the interpretation is used to calculate depth to the magnetic anomalies Table 1.

Table 1: Calculated Depth to Basement from Slope Method

\begin{tabular}{llll}
$\begin{array}{c}\text { Pro- } \\
\text { files }\end{array}$ & $\begin{array}{l}\text { Anoma- } \\
\text { lies }\end{array}$ & $\begin{array}{l}\text { Measured Horizontal distance } \\
(\mathrm{km})\end{array}$ & $\begin{array}{l}\text { Depth } \\
(\mathrm{km})\end{array}$ \\
\hline & $\mathrm{a}$ & 1.3 & 2.366 \\
$\mathrm{~A}-\mathrm{A}$ & $\mathrm{b}$ & 2 & 2.64 \\
& $\mathrm{c}$ & 0.9 & 1.638 \\
& $\mathrm{~d}$ & 1.8 & 3.276 \\
$\mathrm{~B}-\mathrm{B}$ & $\mathrm{e}$ & 2.2 & 4.004 \\
& $\mathrm{f}$ & 0.8 & 1.456 \\
& $\mathrm{~g}$ & 1.5 & 2.73 \\
$\mathrm{C}-\mathrm{C}$ & $\mathrm{h}$ & 1.9 & 3.458 \\
& $\mathrm{i}$ & 0.8 & 1.456 \\
& $\mathrm{j}$ & 1.4 & 2.548 \\
$\mathrm{D}-\mathrm{D}$ & $\mathrm{k}$ & 1.6 & 2.912 \\
& $\mathrm{l}$ & 0.8 & 1.456 \\
& $\mathrm{~m}$ & 0.9 & 1.638 \\
E-E & $\mathrm{n}$ & 2.7 & 4.914 \\
& $\mathrm{o}$ & 0.6 & 1.092 \\
F-F & $\mathrm{p}$ & 2.2 & 4.004 \\
\hline
\end{tabular}

Profile A - $A^{1}$ passes through southwestern part of the study area cutting part of sheet 266 (Auchi area). The anomaly curve shown in Fig 4. The maximum magnetic value along this profile is $60 \mathrm{nT}$ and the minimum is $-20 \mathrm{nT}$. The depth value range along this profile is from $1.6 \mathrm{~km}$ to $3.6 \mathrm{~km}$. Again geological model section of profile $\mathrm{A}-\mathrm{A}^{1}$ show that anomaly "b" contain much sediment as compared to anomaly $\mathbf{a}$ and $\mathbf{c}$.

Also, the maximum magnetic value along Profile $B-B^{1}$ (Fig 4) is $80 \mathrm{nT}$ and the minimum is $-19 \mathrm{nT}$. The depth value range along this profle is $1.5 \mathrm{~km}-4.0 \mathrm{~km}$. The broad part of the curve can be found in anomaly "e" indicating deeper magnetic source while at the end of the profile is a bit sharp indicating shallow magnetic source.

At the profile $\mathrm{C}-\mathrm{C}^{1}$ which cut across part of the Northwestern part and Southeastern part of the study area. The anomaly curve shown in Fig 4 indicates a broader curve at the Northeastern part and a sharp curve at the middle and the extreme portion of the Southeast. The maximum magnetic value along this profile is $150 \mathrm{nT}$ and the minimum is $-100 \mathrm{nT}$. The depth values along this profile ranges from $1.5 \mathrm{~km}$ to $3.5 \mathrm{~km}$.

Moreso, the magnetic intensity in this area is very high as indicated in (Fig 4). The maximum magnetic value along this profile $\mathrm{D}-\mathrm{D}^{1}$ is $200 \mathrm{nT}$ while the minimum is $-100 \mathrm{nT}$. The magnetic intensity in this area is among the highest. The depth value ranges from $1.5 \mathrm{~km}$ to $2.9 \mathrm{~km}$. There are thin elliptical closure or nosing of contour in this profile suggesting the presence of mineral and fault direction.

Furthermore, profile $\mathrm{E}-\mathrm{E}^{1}$ passes through the Northeastern part of the study area. The maximum magnetic value along this profile (Fig 4) is $280 \mathrm{nT}$ and the minimum is $-30 \mathrm{nT}$. The depth value range along this profile is from 1.1 to $4.9 \mathrm{~km}$. The end part of the profile is a bit sharp indicating shallow magnetic source (probably basement rock).
Also, the maximum magnetic value along profile $\mathrm{F}-\mathrm{F}^{\mathrm{l}}$ is $150 \mathrm{nT}$. The profile curve is almost broad indicating deeper magnetic source. The depth to basement in this profile is $4.0 \mathrm{~km}$ (Fig 4).

\subsection{Magnetic basement depth map}

From the computed value from the slope method, the magnetic basement depth map was plotted and contoured using surfer 32 . The deeper magnetic sources vary from 2.3 to $4.9 \mathrm{~km}$, whereas the shallower magnetic source vary from 1.1 to $1.6 \mathrm{~km}$ (Fig 5). The deeper magnetic sources suggest depth to precambrian basement while the shallower depict depths to basic intrusive and/or magnetised bodies. The depth to basement is shallow in the entire north and southwestern part of the study area, while it is deeper in the southeastern part.

From the map, red colour confirms the presence of basement complex and granitic rocks while the blue part of the map rocks while the blue part of the map indicates the sedimentary terrain (Fig 5).

\subsection{Structural pattern of the study area}

The structural pattern were also mapped out from the data obtained as shown in Figs. 6 and 7. The major faults trending in NE-SW and NW-SE direction. The NE-SW trending fault are associated with Kibaran - Orogeny. This orogeny is marked with geosynelinal sedimentation and metamorphism.

\section{Conclusion}

The slope method is mostly used as a quick check on the validity of depth estimation. The method gives reasonable results and it is very suitable for anomaly survey and analysis. The result of the analysis shows that the depth to basement varies between 1.1 to $4.9 \mathrm{~km}$, with the average depth to deeper sources ranging from 2.3 to $4.9 \mathrm{~km}$ while that of the shallower sources ranging from 1.1 to $1.6 \mathrm{~km}$. The interpretation of the aeromagnetic map of Lokoja and its environ revealed that the sedimentary cover is generally low in the northwestern and southwestern parts and as such this area is not likely to favour hydrocarbon formation. Also hydrocarbon prospects are highly doubtful because of the presences of basement rock within the area. The emplacement of this rock may have destroyed the geological structures that could have served as hydrocarbon traps. The broad regional magnetic signature of the area is a reflection of the magnetic property of the area. Furthermore, the trend system is approximately trending NE-SW and NW-SE direction. The NE-SW trending faults are association with Kibaran orogeny. This orogeny is marked with geosynelinal sedimentation and metamorphism.

\section{References}

[1] Amigun, J.O., and Ako, B.D., 2009. Rock density- A tool for mineral prospection: A case study of Ajabanoko iron ore deposit, Okene SW Nigeria. The pacific journal of science and technology, vol.10, pp.733-744.

[2] Chinwuko, A. I., Onwuemesi, A. G., Anakwuba, E. K., Onuba, L. O., and Nwokeabia, N. C., 2012. Interpretation of Aeromagnetic Anomalies over parts of Upper Benue Trough and Southern Chad Basin. Nigeria. Advances in Applied Science Research, Vol. 3 (3), pp.17571766.

[3] Nsikak, E.B., Nur, A., and Gabriel, I.D., 2000. Analysis of Aerial photographics data over Guyuk Area, Northeastern Nigeria. Journal of Mining and Geology, Vol. 36, No.2, pp.145 - 152.

[4] Obaje, N.G.J (2009). The Bornu Basin - Nigerian Sector of the Chad Basin. Journal of Geology and mineral, Vol. 120/2009, pp.69-76.

[5] Ofoegbu, C.O., 1988. An aeromagnetic study of part of the upper Benue Trough Nigeria. Journal of African Earth Science, Vol.7, pp.77-90. 
[6] Olade, M.A., 1975. Evolution of Nigeria's Benue Trough. African Lithosphere and their Geodynamic Significance. Journal of African Earth Science, Vol. 3, pp.437 - 442.

[7] Onuba, L.N., Onwuemesi, A.G., Anudu, G.K, Chiaghanam, o.I. and Ifelunni,C.D., 2008. Interpretation of aeromagnetic anomalies over Benue Trough, Northeastern, Nigeria. Journal of Natural and applied sciences, vol.9, pp.1-12.

[8] Onuba, L.N., Anudu, G.K., Chiaghanam, O.I and Anakwuba, E.K, 2011. Evaluation of aeromagnetic anomalies over Okigwe area, Southeastern Nigeria. Research journal of environment and earth sciences.pp.498-506.
[9] Rasheed, A.A., Jide, M. A. and Chinwuba, A., 2011. Slope stability analysis of Itakpe iron ore mine, Itakpe, Nigeria. Journal of engineering, pp.602-604.

[10]Spector, a Grant, F.S., 1979. Statistical model for interpreting Aeromagnetic data. Geophysics, 25, pp.293-302.

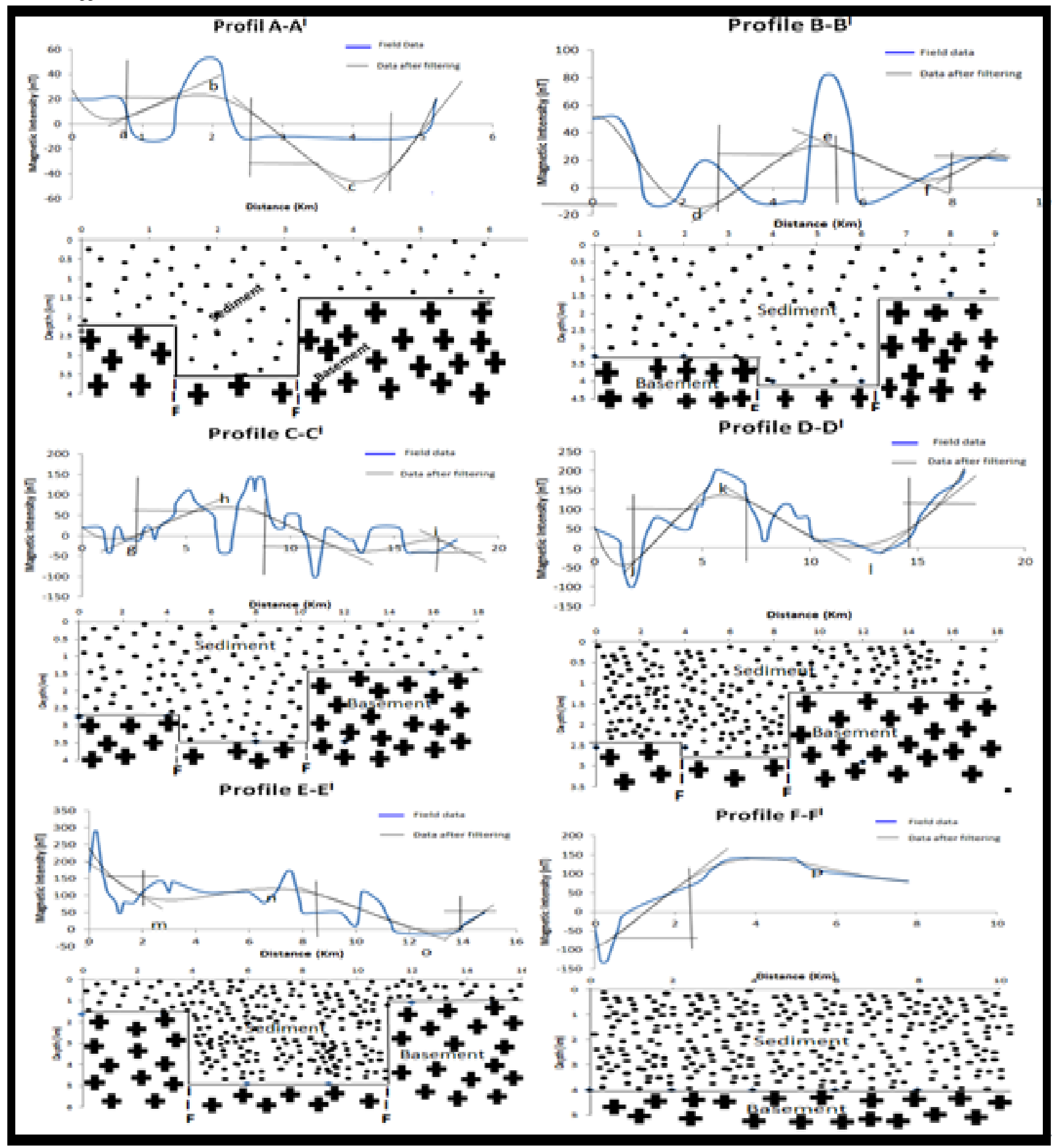

Fig. 4: Geological Model Section of Various Anomalies 


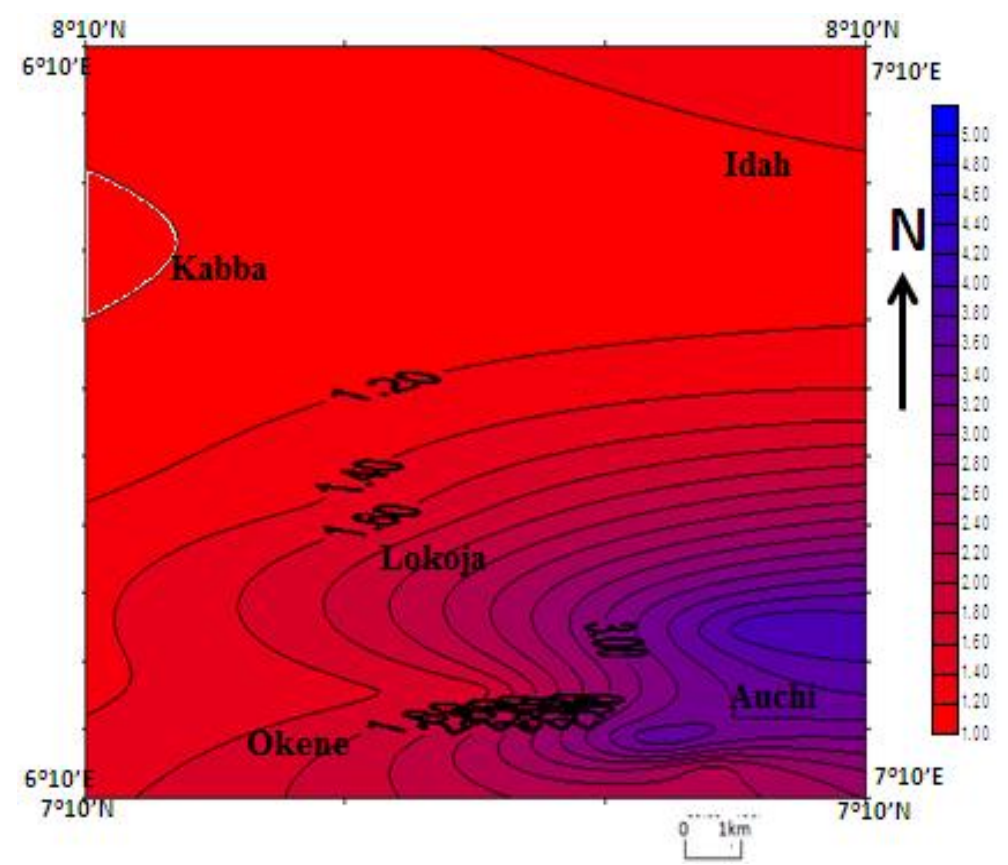

Fig. 5: Depth to Basement Map of the Study Area. (Contour Interval 0.1km)
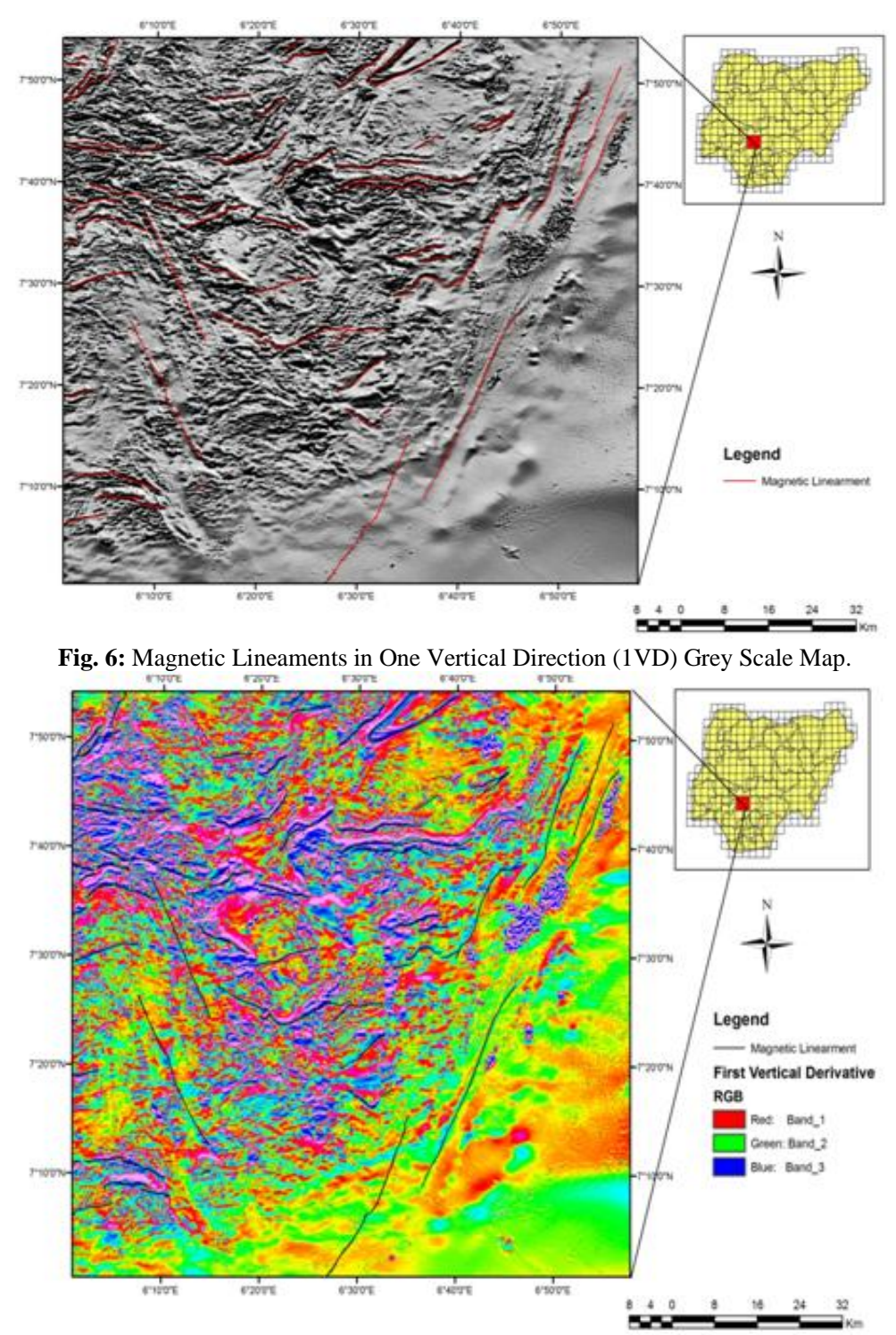

Fig. 7: Magnetic Lineament in First Vertical Derivative Map. 